УДК: 620.178.7

DOI: 10.37128/2520-6168-2021-1-10

Vol. 112, No 1 / 2021

\title{
RESEARCH OF PROCESS OF DIVISION OF GRADE ROLLING ON THE MEASURED BLANKS BY METHOD OF BREAKING BEND AT STATIC AND SHOCK LOADING
}

\author{
Sergii Karnaukh, Ph.D., Associate Professor \\ Igramotdin Aliiev, Doctor of Technical Sciences, Full Professor \\ Donbass State Engineering Academy \\ Карнаух Сергій Григорович, к.т.н, доцент \\ Алієв Іграмотдін Серажутдінович, д.т.н., професор \\ Донбаська державна машинобудівна академія
}

Research of the process of cold breaking of rolling by bending under static and shock loads was conducted to determine the effect of loading speed on the power parameters of the separation process and the quality of the workpieces. Experimental researches are conducted for the three-point cold breaking by bending of templates from steel of different brands at the static and shock loading with the use of original equipment and rigging. Comparison of maximal force of breaking at the static and shock loading was estimated by the coefficient of dynamic, which for the different brands of steel laid down accordingly: WIX15 - 0, 7; 60C2 - 1,6; $45-2,0.2,2 ; 40 X-1,8.2,1 ; 20-1,6.1,8$ at speed of deformation to $18 \mathrm{~m} \mathrm{c}$. At the increase of speed of deformation the coefficient of dynamic grows for materials in the plastic and viscidly-resilient state and diminishes for materials in the fragile state. Than higher plasticity of material of templates, the greater size of coefficient of dynamic.

Obviously, that for the exposure of inclination of materials of templates to fragile destruction it is necessary to apply the higher values of speed of loading. With the growth of speed of deformation geometrical exactness of blanks from the different brands of steels, gets better, but not significant. The most high quality was shown by blanks at the division of standards from fragile and viscoelastic steels: $U X$ 15, steel of 60C2, steel 45, steel of 40X. It is identified that greater part of energy of deformation is spent on an origin and viscid growing up of crack, while energy expended on fragile destruction is insignificant. Got results can be used for the improvement of the technologies of process of division of grade rolling on the measured blanks by the method of the cold breaking by a bend.

Key words: breaking bend, force, statics, blow, quality, rolling, blanks, dynamic factor.

Fig. 6. Table. 1. Ref. 8.

\section{Introduction}

Among the known waste-free methods of cut out of high quality rolling the special place is occupied by breaking bend, which is based on the directed destruction of the cut rolled during bending. The method of cold breaking by bending has low energy consumption, ease of implementation, the ability to separate hard and high-strength materials without heating. However, the full advantages of bending fracture can be used only if additional measures are taken to radically improve the quality of chipping and reduce the energy consumption of the fracture process, because the elastic-stress state is formed throughout the rolled section and only a small part of elastic energy goes to crack development. Other part of resilient energy is spent on a flowage in a macrovolume - in the area of contact with a shock instrument and supports [3].

In addition, as a result of the analysis of the regularities of deformation and destruction of rolled metal, it was found that the development of geometric defects during fracture is also caused by plastic deformation during separation $[3,4]$.

One of the promising ways to reduce the level of plastic deformation is the use of high load speeds. A large merit in the study of questions of influence of speed of deformation on property of durability of metals belongs to the scientists: Ioffe O.F., Davidenkov N.N., Shevandin Ye.M., Gopkinson D., Erdogan E., Ekobori T., Pirson D., Sokolov L.D., Napivkhin P.I., Gun G.Ya., Galkin O.M., Parton V.Z. and others [1-8].

Development of new high-speed processes of division of high quality rolling on the measured blanks must be based on the modern methods of experimental analysis. Knowledge of the conduct of material at the shock loading - one of necessary terms of correct choice of the technological modes of process of division [5]. 


\section{Problem formulation}

Important direction of improvement of machine-building production is the development of ways of the cost of metal cutting in a purveying production and also the increase of exactness and productivity of cut out of rolling, as the noted factors substantially influence on the technical and economic indexes of next processes of production [1-5].

However, determination of size of arising up at a blow effort, through small enough duration of collision, presents the known problem. The briefness of action of loading and appearance of wave effects with the height of speed of deformation considerably complicate the analysis of conduct of material and influence of speed of loading on his mechanical properties [4].

Numerous experimental data testify to the sensitiveness of materials to speed of loading, that speed of loading can, both to increase and diminish descriptions of durability depending on a structure, composition and technologies of their receipt. However, published experimental data are contradictory and it's volume unsuffices, especially in relation to the processes of division of high quality rolling on the measured blanks [3].

\section{A purpose of work}

A purpose of work is research of the process of the cold breaking of rolling by bending at the static and shock loading for determination of influence of speed of loading on the power parameters of process of division and quality of blanks.

In order to obtain such data, experimental studies on three-point cold fracture by bending samples of steel of different grades under static and shock loads were performed [5].

\section{Results of research}

During the experiments, a press hammer was used as equipment (Fig. 1), a structure of the Donbas State Machine-Building Academy (DSMA), which provides the ability to create quasi-static, shock and combined loads in a wide range of speeds, energies and forces and has the following characteristics: maximum energy blow - 1,3 $\mathrm{kDh}$; force developing by the press part - $106 \mathrm{kH}$; the maximum theoretical speed of the moving parts of the machine $-24,6 \mathrm{~m} / \mathrm{s}$ and the corresponding stroke of the rod $-114,6 \mathrm{~mm}$; battery capacity $-12 \cdot 10^{-3} \mathrm{~m}^{3}$; maximum working pressure $-18 \mathrm{M \Pi a}$; mass of moving parts $-6,25 \mathrm{~kg}$ [7].

For carrying out experiments the installation for division of samples by a method of cold breaking by a bend consisting of a bed 1 in which guides mechanisms of a clip of hire, a breaker and the supports established with a possibility of the translational movement limited by stops 2 and overlays 3 which fasten to a bed with 1 bolts. The position of the clamping mechanisms, breaker and supports is fixed by bolts 5 screwed into the stops 2 , nuts 4 and spacers 6 . The rolling clamp mechanism consists of a housing 7 , in the hole of which is a sample 15 between the half-sleeves 8 , which are clamped by a bolt 9 screwed in the housing 7 . The mechanism of the breaker consists of the housing 10 , the striker 11, installed with the possibility of translational movement in the guides of the housing. The support mechanism consists of a housing 12 and a support plate 13, which is held by the pad 14 by means of bolts with washers [5,8].

A structural chart and picture of the experimental rigging (Fig. 1, a), picture of experimental equipment (Fig. 1, b) and chart of realization of experiment (Fig. 1, B), is brought around to Fig. 1.

Foil strain gages FKTK $10200 \mathrm{C}$ I, included according to the half-bridge scheme, were used as strain gages for registration of efforts on a fight and support of equipment. Information from strain gauges through a universal device for multichannel information collection E-440 was fed to a PC, where after processing using the original program was stored in tabular and graphical form, convenient for further analysis $[5,8]$.

In an experiment cylindrical standards were used from rolling with diameter $16 \mathrm{~mm}$ and long $150 \mathrm{~mm}$ from the different brands of steel, that are in plastic - Ct. 3, in resiliently-plastic - Steel: 20, 45, 40X and in fragile state - Steel: 60C2, WX15. Stress concentrators in the form of an annular groove of a triangular profile were previously applied to the samples by means of a turning cutter with such parameters: depth $-\Delta h=1 \mathrm{~mm}$ and $\Delta h=3 \mathrm{~mm}$, a radius at a top $-0,15 \mathrm{~mm}$. Shoulder of appendix of loading $-50 \mathrm{~mm}$ [7]. 

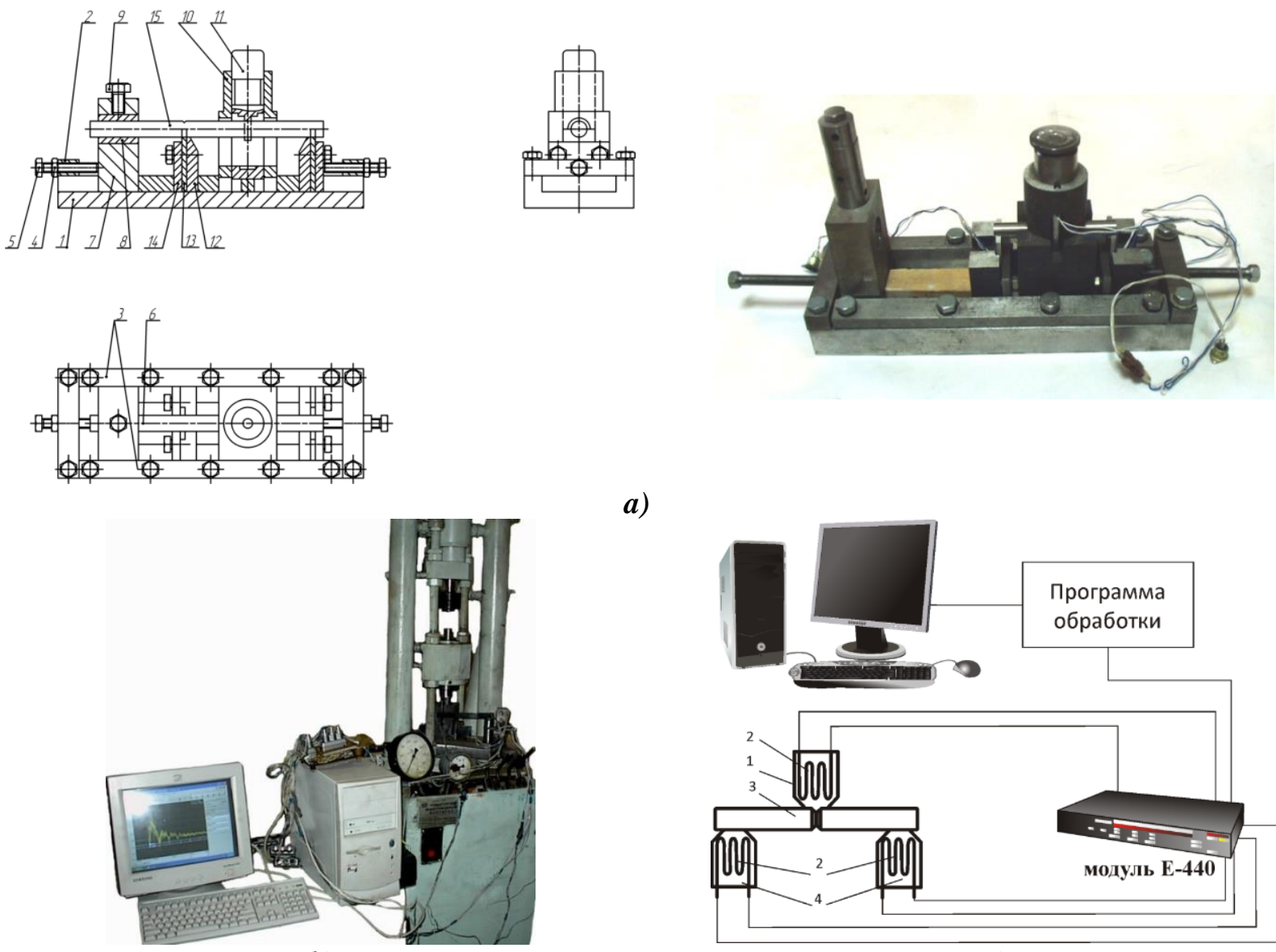

a)

b)

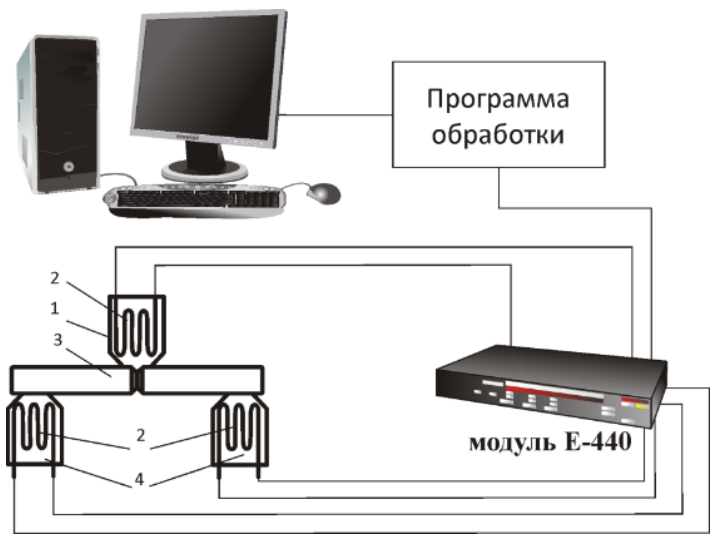

c)

Fig. 1. Structural chart and picture of the experimental rigging (a), picture of experimental equipment (b) and chart of realization of experiment (c) [5,8]

Measuring of geometrical parameters which characterize geometrical exactness of the divided standards, was conducted by the method of macrostructural analysis with measuring of absolute and relative values of curvatures of geometrical form with the use of universal measuring instrument.

Typical graphics of change of power parameters of process of the three-point cold breaking by a bend from time at the division of standards from the different brands of steel with the concentrator of tensions $\Delta h=3 \mathrm{~mm}$ at the static and shock loading presented on Fig. 2.

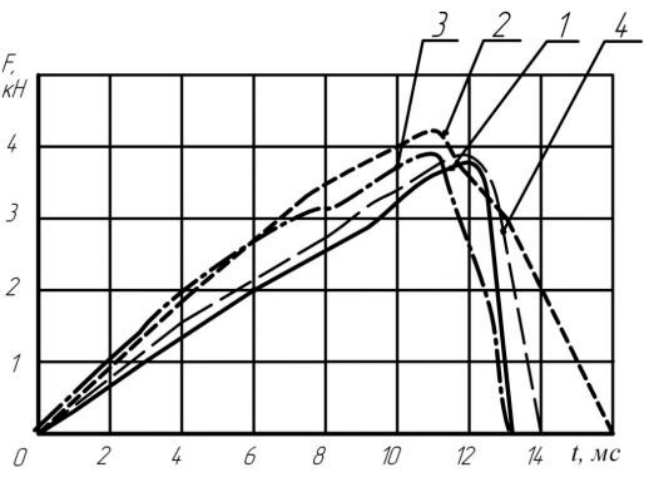

a)

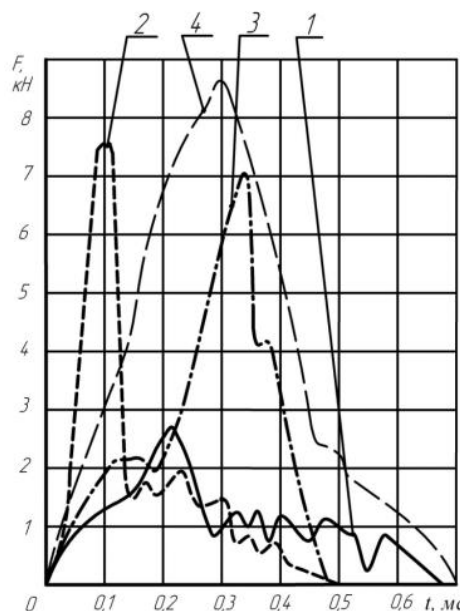

b)

Fig. 2. Dependence of force on a firing-pin from time for standards from the different brands of steel at $\Delta h=3 \mathrm{~mm} 1$-Steel IIX15; 2 -Steel 20; 3 -Steel 40X; 4 -Steel 45

$a$-at the static loading; $b$-at the shock loading 
Typical oscillogram which is taken off from a firing-pin and supports (testimony of three channels which are taken off simultaneously) for standards from steel of brand of $60 \mathrm{C} 2$ at $V=18 \mathrm{~m} / \mathrm{s}$ presented on Fig. 3.

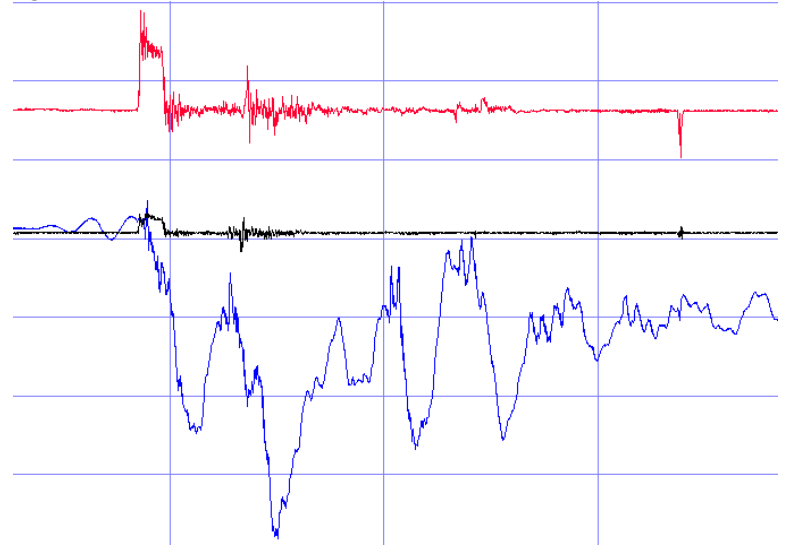

Fig. 3. Typical oscillogram which is taken off from a firing-pin and supports (testimony of three channels which are taken off simultaneously) for standards from steel of brand of $60 C 2$ at $V=18 \mathrm{~m} / \mathrm{s}$ : axis of $X-$ time, $a$ scale - 100000 measuring in $1 \mathrm{~s}$.

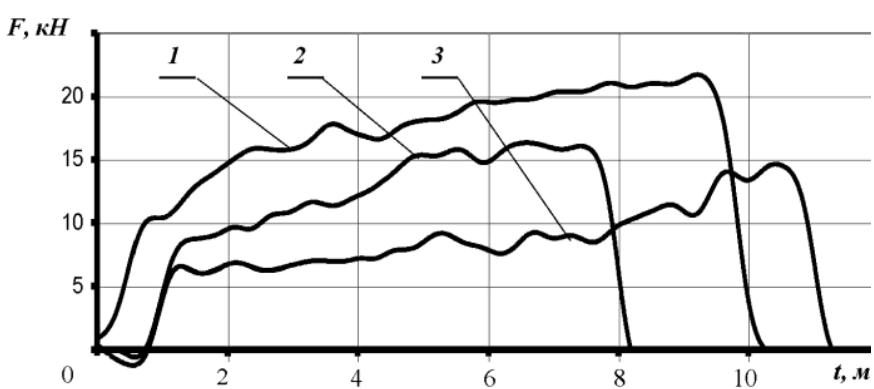

Fig. 4. Dependence of static force is on a firing-pin from timefor the different brands of steel at $\Delta h=1 \mathrm{~mm} 1$ - Steel 60C2; 2 - Steel 45; 3 - Ct. 3

Change of force of breaking $F(t)$ at the three-point breaking of standards with the concentrator of tensions $\Delta h=1 \mathrm{~mm}$ at the static and shock loading presented on Fig. 4,5.

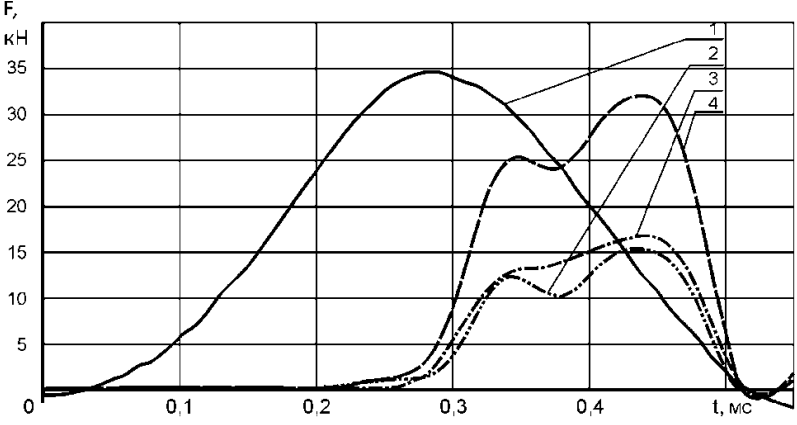

a)

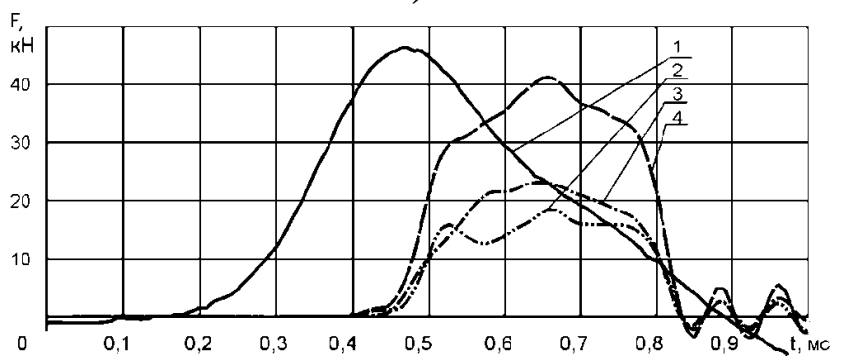

c)

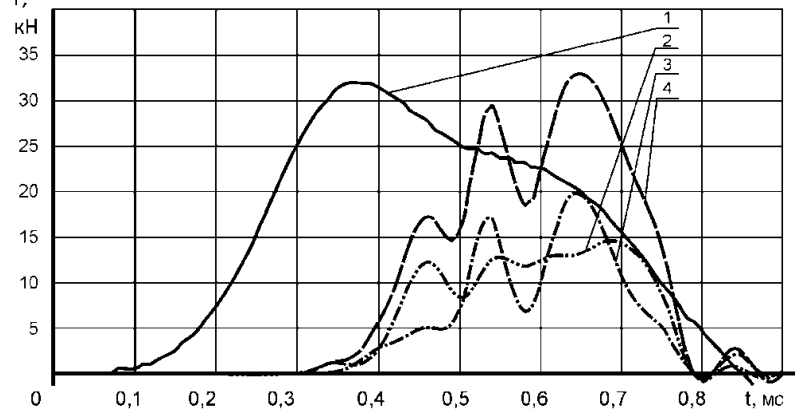

b)

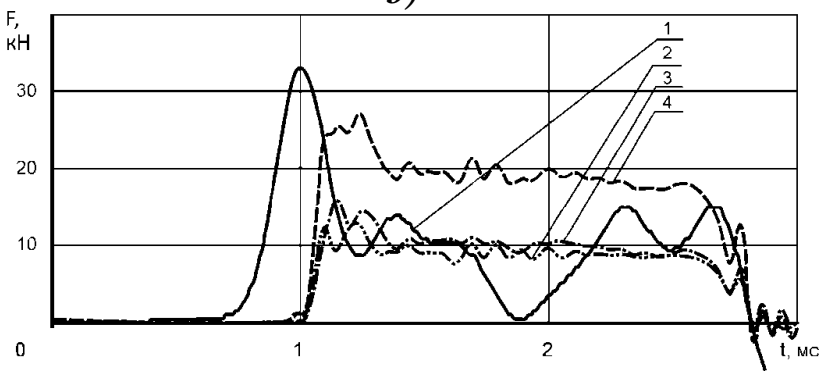

d)

Fig. 5. Graphics of change $F(t)$ of force on a firing-pin and supports (a testimony is from three channels which are taken off simultaneously) for the different brands of steel at the shock loading $(V=18 \mathrm{~m} / \mathrm{s}$ ) on the chart of the three-point breaking by a bend at $\Delta h=1 \mathrm{~mm}$ $a$-Steel 60C2; b-Steel 45; $c$-Steel 40X; d-Steel 20

Results of the conducted experimental researches and additional calculations presented in Table. 1. 
Vol. 112, No 1 / 2021

Table 1

Results of experiments

\begin{tabular}{|l|c|c|c|c|c|}
\hline \multirow{3}{*}{ Mark of steel } & \multicolumn{4}{|c|}{ Maximal force of breaking $F_{л}, \kappa H$} & \multirow{2}{*}{ Dynamic factor } \\
\cline { 2 - 5 } & \multicolumn{2}{|c|}{$\Delta h=3 \mathrm{~mm}$} & \multicolumn{2}{c|}{$\Delta h=1 \mathrm{~mm}$} & \\
\cline { 2 - 5 } & statics & dynamics & statics & dynamics & \\
\hline Steel ШX15 & 3,8 & 2,7 & - & - & 0,7 \\
\hline Steel 60C2 & - & - & 22,0 & 35,0 & 1,6 \\
\hline Steel 45 & 3,9 & 8,6 & 16,0 & 32,0 & $2,0 \ldots 2,2$ \\
\hline Steel 40X & 3,9 & 7,0 & 21,0 & 45,0 & $1,8 \ldots 2,1$ \\
\hline Steel 20 & 4,2 & 7,5 & 22,0 & 35,0 & $1,6 \ldots 1,8$ \\
\hline
\end{tabular}

Comparison of maximal force of breaking at the static and shock loading was estimated by the dynamic factor $k_{\partial}=F_{л д} / F_{л с}$ (see a table. 1), which for the different brands of steel laid down accordingly: Steel ШX15-0,7; Steel 60C2-1,6; Steel 45-2,0..2,2; Steel 40X-1,8..2,1; Steel $20-1,6 . .1,8$. Obtained results satisfactorily comport with data, resulted in literature [3] (taking into account that experiments were conducted at speed of loading $V=18 \mathrm{~m} / \mathrm{s}$ ) where dynamic factor with the height of speed of deformation a to $100 \mathrm{~m} / \mathrm{of}$ c for an armco-iron increases in 3,4 times; for Steel 45 - in 2,8 times; for steel Ct 3 - in 2,9 times; for steel ШX 15 - less than 1,0 (explained by the initial processes of destruction in a metal and allows to consider a structural factor qualificatory on the initial stage of high-speed tests of materials).

Pictures of standards from the different brands of steel, divided on the chart of the three-point cold breaking by a bend at the shock loading presented on Fig. 6. Description of geometrical exactness of interphase of blanks was conducted on the known methods [3].

A blank from steel $60 \mathrm{C} 2$ is got by fragile destruction, the surface of destruction is mat, there is a small tear-out from the side of area of squeezing tensions, the trajectory of crack is rectilineal, the areas of standard near-by the concentrator of tensions practically are not deformed. Quality of blanks is high (see fig. 6, a).

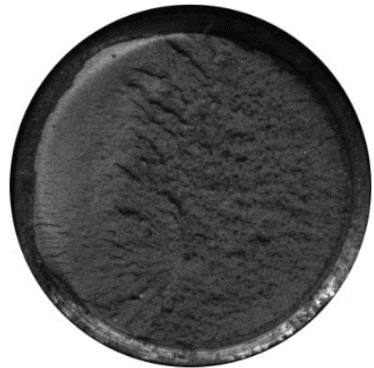

a)

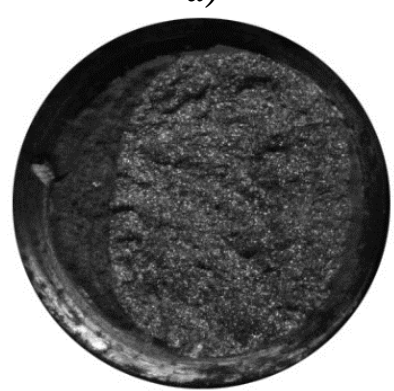

c)

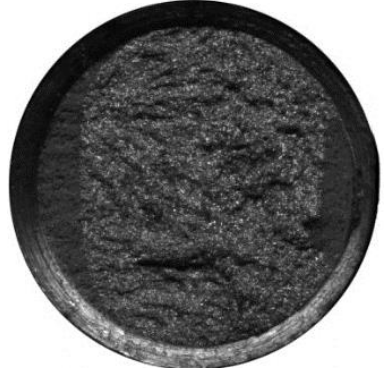

b)

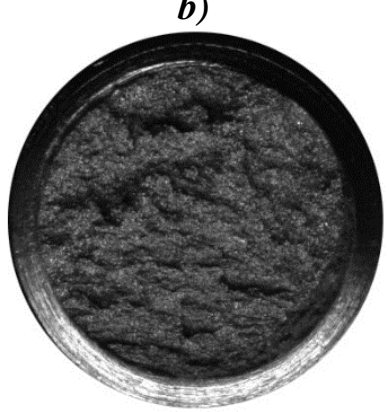

d)

Fig. 6. Pictures of standards: a-Steel 60C2; b-Steel 45; $c$-Steel 40X; d-Steel 20

Standard from steel 45 has next descriptions of geometrical exactness: destruction is fragile, surface of destruction ofstriped, rough with the size of faction a $0,2 \ldots 0,3 \mathrm{~mm}$, the trajectory of crack is rectilineal. The areas of blanks which join to the concentrator of tensions are not practically outbowed (see fig. 6, b). Quality of blanks is satisfactory.

A standard from steel $40 \mathrm{X}$ has next descriptions of geometrical exactness: destruction is viscidly resilient, surface of destruction of striped, coarse-grained with tear-outs (faction is a $0,3 \ldots 0,4 \mathrm{~mm}$ ), areas nearby the concentrator of tensions are deformed poorly (see rice. 6, c). Quality of blanks is satisfactory. 
Standard from steel 20 has next descriptions of geometrical exactness: destruction is viscidly resilient, surface of destruction of striped, coarse-grained with tear-outs (faction is a $0,6 \ldots 0,8 \mathrm{~mm}$ ), areas near-by the concentrator of tensions are deformed poorly (see rice. 6, d). Quality of blanks is satisfactory.

Thus, with increasing the speed of deformation, the geometric accuracy of obtained from samples of different steel grades improves, but insignificantly. Most of the energy is spent on the nucleation and viscous growth of the crack, while the energy spent on brittle fracture is negligible. There is leakage of the crack at room temperature, which is inherent in the brittle fracture, which is consistent with the data of the experiment [3] at temperatures below $50^{\circ} \mathrm{C}$.

\section{Conclusions}

1. Values of dynamic factor at the shock loading of standards with different mechanical properties on the chart of the three-point breaking by a bend were defined. On the whole at the increase of speed of deformation the dynamic factor grows for materials in the plastic and viscidly-resilient state and diminishes for materials in the fragile state. The higher plastic properties of material of standards, the greater size of dynamic factor. For the exposure of inclination of materials of standards to fragile destruction it is necessary to apply the higher values of speed of loading - to $50 \mathrm{~m} / \mathrm{s}$.

2. With the increase of speed of deformation, geometrical exactness of blanks, obtained from standards from the different brands of steel, gets better, but not significant. Greater part of energy is spent on an origin and viscid growing up of crack, while energy expended on fragile destruction is insignificant.

3. Obtained results can be used for improvement of the technologies of process of division of the grade rolling on the measured blanks by the method of the cold breaking by a bend.

\section{References}

[1] Gutknecht, F., Steinbach, F., Hammer, T., Clausmeyer, T., Volk, W., Tekkaya, A.E. (2016). Analysis of shear cutting of dual phase steel by application of an advanced damage model. Procedia Struct. Integr. 2: 1700-1707. https://doi.org/10.1016/j.prostr.2016.06.215. [in English].

[2] Yadav, S., Feng, G., Sagapuram, D. (2019). Dynamics of shear band instabilities in cutting of metals. CIRP Ann. 68: 45-48. https://doi.org/10.1016/j.cirp.2019.04.030. [in English].

[3] Finkel, V. M., Rodyukov, G. B., Golovin, Yu. I. (1982). Kholodnaya lomka prokata. Moskva: Metallurgiya. [in Russian].

[4] Polukhin, P.I., Gorelik, S.S., Voronczov, V.K. (1982). Fizicheskie osnovy` plasticheskoj deformaczii. M.: Metallurgiya. [in Russian].

[5] Karnaukh, S. G. (2010). Sovershenstvovanie bezotkhodny`kh sposobov razdeleniya sortovogo prokata i oborudovaniya dlya polucheniya zagotovok vy`sokogo kachestva : monografiya. Donbasckaya gosudarstvennaya mashinostroitel naya akademiya. Kramatorsk. [in Russian].

[6] Karnaukh, S., Markov, O., Aliieva, L., Kukhar, V. (2020). Designing and researching of the equipment for cutting by breaking of rolled stock. The International Journal of Advanced Manufacturing Technology. 109. Issue 9-12. 2457-2464. https://doi.org/10.1007/s00170-020-05824-7. [in English].

[7] Karnaukh S.G., Karnaukh D.S. (2011). Research of the influence of deformation speed on energy and power adjectives of the process of three-point cold bend breaking and on alignment integrity of raw parts. Metallurgical and Mining Industry. Dnepropetrovsk. №3. Vol.3. 107-114. [in English].

[8] Karnaukh, S.G. (2017). Development of the choice procedure for separation method of section iron complex criteria of materials destruction. Mechanics and Advanced Technologies. 2(80). 31-38.

\section{ДОСЛІДЖЕННЯ ПРОЦЕСУ РОЗДІЛЕННЯ СОРТОВОГО ПРОКАТУ НА МІРНІ ЗАГОТОВКИ СПОСОБОМ ЛОМКИ ЗГИНОМ ПРИ СТАТИЧНОМУ ТА УДАРНОМУ НАВАНТАЖЕННІ}

В роботі проведено дослідження процесу холодної ломки прокату згином при статичному $i$ ударному навантаженні для визначення впливу швидкості навантаження на енергосилові параметри прочеесу розділення та якість заготовок. Експериментальні дослідження проведені для триточкового холодного ламання згином зразків зі сталей різних марок при статичному і ударному навантаженні із використанням оригінального обладнання і оснастки. Порівняння максимальної сили ламання при статичному і ударному навантаженні оцінювалося коефічієнтом динамічності, який для різнихмарок сталей склав відповідно: ШХ15-0, 7; 60C2-1,6; 45 - 2,0...2,2; 40X-1,8..2,1; 20 - 1,6..1,8 при швидкості деформування до $18 \mathrm{M} / \mathrm{c}$. При зростанні швидкості деформування коефіцієнт динамічності зростає для матеріалів у пластичному та в'язко-пружному стані і зменшується для матеріалів у крихкому стані. Чим вище пластичність матеріалу зразків, тим більща величина коефіцієнта динамічності. Очевидно, щуо для виявлення схильності матеріалів зразків до крихкого руйнування треба 


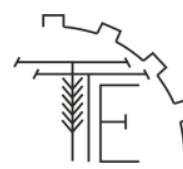

застосовувати більш високі значення швидкості навантаження. Із підвищенням швидкості деформування геометрична точність заготовок із різних марок сталей, поліпшується, але несуттєво. Найбільш високу якість показали заготовки при розділенні зразків із крихких та в'язкопружних сталей: ШХ 15, сталь 60С2, сталь 45, сталь 40Х. Встановлено, шуо більша частина енергї̈ деформування витрачається на зародження $i$ в'язке підростання тріщини, тоді як енергія, затрачувана на крихке руйнування, є незначною. Отримані результати можуть бути використані для вдосконалювання технології процесу поділу сортового прокату на мірні заготовки способом холодної ломки згином.

Ключові слова: ломка згином, сила, статика, удар, якість, прокат, заготовка, коефіиієнт динамічності.

Рис. 6. Табл. 1. Лім. 8.

\section{ИССЛЕДОВАНИЕ ПРОЦЕССА РАЗДЕЛЕНИЯ СОРТОВОЙ ПРОКАТКИ НА МЕРНЫЕ ЗАГОТОВКИ МЕТОДОМ РАЗРІВНОГО ИЗГИБА ПРИ СТАТИЧЕСКОЙ И УДАРНОЙ НАГРУЗКЕ}

В работе проведено исследование прочесса холодной ломки проката изгибом при статическом и ударном нагружении для определения влияния скорости нагружения на энергосиловые параметры процесса разделения и качество заготовок. Экспериментальные исследования проведень для трехточечной холодной ломки изгибом образцов из сталей различных марок при статической и ударной нагрузке с использованием оригинального оборудования и оснастки. Сравнение максимальной силь ломки при статической и ударной нагрузке оченивалось коэффициентом динамичности, который для различных марок сталей составил соответственно: ШХ15-0, 7; 60С2 - 1,6; 45 - 2,0...2,2; $40 X-1,8 \ldots 2,1 ; 20$ - 1,6..1,8 при скорости деформирования до $18 \mathrm{M} / \mathrm{c}$. При увеличении скорости деформирования коэффиџиент динамичности увеличивается для материалов, находящихся в пластическом и вязко-упругом состоянии, и уменьшается для материалов в хрупком состоянии. Чем выше пластические свойства материала образцов, тем больше величина коэффициента динамичности. Очевидно, что для вылвления склонности материалов образиов к хрупкому разрушению необходимо использовать более высокие значения скорости нагружения. С повышением скорости деформирования геометрическая точность заготовок, полученных из образцов из различных марок сталей, улучшается, но незначительно. Наиболее высокую точность заготовок получили при разделении образияов из хрупких и вязкоупругих сталей: ШХ 15, Сталь 60С2, Сталь 45, Сталь 40Х. Большая часть энергии расходуется на зарождение и вязкое подрастания трещины, тогда как энергия, затрачиваемая на хрупкое разрушение, незначительна. Полученные результаты могут быть использованы для совершенствования технологии процесса разделения сортового проката на мерные заготовки способом холодной ломки изгибом.

Ключевые слова: ломка изгибом, сила, статика, удар, качество, прокат, заготовка, коэффициент динамичности.

Рис. 6. Табл. 1. Лит. 8.

Карнаух Сергій Григорович - к.т.н., доцент, зав. кафедрою «Основ проектування машин» Донбаської державної машинобудівної академії (вул. Академічна, 72, м. Краматорськ, 84313, Україна, етаil: k sergii@i.ua, https://orcid.org/0000-0003-2878-4065 )

Алісв Іграмотдін Серажутдінович - д.т.н., професор, Донбаська державна машинобудівна академія вул. Академічна, 72, м. Краматорськ, 84313, Україна, email: igramaliev@gmail.com, https://orcid.org/0000-0002-4248-8214 )

Карнаух Сергей Григорьевич - к.т.н., доцент, зав. кафедры «Основы проектирования машин» Донбасской государственной машиностроительной академии (ул. Академическая, 72, г.. Краматорск, 84313, Украина, email: k sergii@i.ua, https://orcid.org/0000-0003-2878-4065).

Алиев Играмотдин Серажутдинович - д.т.н., профессор, Донбасская государственная машиностроительная академия (ул. Академическая, 72, г.. Краматорск, 84313, Украина, етаil: igramaliev@gmail.com, https://orcid.org/0000-0002-4248-8214).

Sergii Karnaukh - Ph.D., Associate Professor of the Department "Fundamentals of Machine Design" of the Donbass State Engineering Academy (st. Akademicheskaya, 72, Kramatorsk, 84313, Ukraine, email: k_sergii@i.ua, https://orcid.org/0000-0003-2878-4065).

Igramotdin Aliiev - Dr Sc. (Eng.), Full Professor; Donbass State Engineering Academy (st. Akademicheskaya, 72, Kramatorsk, 84313, Ukraine, email: igramaliev@gmail.com, https://orcid.org/00000002-4248-8214). 